\title{
CONSTRUCT A STATE OF WELFARE (AN STUDY ON THE IMPROVEMENT OF WELFARE THROUGH THE SOCIAL SECURITY SYSTEM IN INDONESIA)
}

\author{
Dyah Asri Gita Pratiwi \\ Politeknik Kesejahteraan Sosial \\ dyahasrigita@yahoo.com \\ Didit Susiyanto \\ PT. Bhumi Jati Power \\ didit.susiyanto@pt-bjp.co.id
}

\begin{abstract}
Poverty is still inherent in every aspect of human life, so it requires comprehensive, integral, and sustainable countermeasures. Indonesia has made a national commitment to eradicate poverty in the context of implementing sustainable development, where the government and all state apparatuses together with various elements of society bear the primary responsibility for achieving sustainable development and simultaneously alleviating poverty. International and national commitments strongly emphasize the importance of social security, especially as a strategy to deal with poverty in a systemic, institutionalized and integrated manner. The development of a social security system program to support the achievement of people's welfare needs to be seen as an effort to restore the community's ability to achieve their own welfare. In Indonesia, the development of a social network system as an alternative to improving people's welfare can be done by revamping the mechanism for implementing a social assistance program that is not centralized, which accommodates the diversity of local characteristics and demands as well as the integration and strong relationship between the management of economic development fields and the field of social welfare. In addition, the social security system needs to be strengthened as an infrastructure of social capital for the community towards a stable life.
\end{abstract}

Keywords:

Welfare State; Social Security System; Poverty; Social Welfare. 


\section{INTRODUCTION}

In the development process carried out by the nations of the world, poverty is a phenomenon that is always strived to be minimized, maybe even eliminated. However, in reality, poverty is still inherent in every aspect of human life, so it requires comprehensive, integral, and sustainable efforts to overcome. In this regard, the leaders of countries in the world at the Millennium Summit at the United Nations (UN), New York in 2000, set efforts to reduce half of the poverty in the world as "Millennium Development Goals" for UN member countries that must be achieved by 2015 through 8 (eight) target channels, namely: (1) Halve the proportion of the world's population who earn less than the US \$ 1 per day and the proportion of the population suffering from hunger; (2) Halve the proportion of the population who do not have access to safe drinking water; (3) Ensure that all children, boys, and girls, complete primary school; (4) Reducing up to $2 / 3$ of the mortality of infants and children under the age of five; (5) Stop the spread of HIV / AIDS, malaria, and other types of infectious diseases; (6) Eliminating gender inequality in schools; (7) Consequently applying sustainable development policies; and (8) Develop partnerships for development at all levels. The commitment of all nations in the world to eradicate poverty from the face of the earth was reaffirmed in the "Johannesburg Declaration on Sustainable Development" which was agreed upon by the Heads of State / Government of 165 countries who attended the Sustainable Development Summit (Summit) in Johannesburg, Africa. South, in September 2002, and then outlined in the document "Plan for the Implementation of the Sustainable Development Summit," which was also signed by the President of the Republic of Indonesia, to become a reference in implementing development in Indonesia. Thus, Indonesia has made a national commitment to eradicate poverty in the context of implementing sustainable development, where the government and all state apparatus together with various elements of society bear the main responsibility for realizing sustainable development and at the same time alleviating poverty, by 2015 at the latest.

As is well known, economic development clearly greatly affects the level of prosperity of a country. However, economic development that is completely left to the market mechanism will not automatically bring prosperity to all levels of society. The experiences of developed and developing countries prove that although the market mechanism is capable of producing optimal economic growth and employment opportunities, it always fails to create income distribution and eradicate social problems.

The poor and people with social welfare problems (PMKS) are groups that are often not touched by development strategies that rely on market mechanisms. This vulnerable group, due to their physical (disabled), cultural, and structural (unemployed) obstacles, is unable to respond as quickly as the social changes around them, are thrown aside in an unfair development process. That is one of the reasons why developed countries try to reduce this gap by implementing a welfare state, a system that gives a bigger role to the state (government) in the development of planned, institutionalized, and sustainable social welfare.

Due to the imperfection of this market mechanism, the role of government is largely shown in its function as an agent of economic 
and social development. This means that the government is not only tasked with encouraging economic growth, but also expanding the distribution of the economy by allocating public expenditure in the APBN and binding public policies. In addition to its nation-state management policy, the government rewards productive economic actors, it also provides allocation of funds and resources to ensure equity and compensation for those who are scattered from development competition.

Various efforts to overcome social problems in Indonesia continue to be carried out, but the approach used is still patchy (adhoc), not integrated, and unsustainable. Antipoverty policies and programs, for example, are still project-oriented, which relies on the kiss and run strategy. This means that poverty is handled partially with a very limited scheme and geographic coverage. Such an approach model will never completely eradicate poverty because the strategy is not directed at eradicating poverty, but rather eradicating the poor. Poverty alleviation will never be effective by only touching the poor. Poverty is a structural product of an interrelated system, namely the economic system (growth and distribution of national income), education (empowerment and human resource development), and social security (social assistance and social insurance).

The national development strategy so far has been concerned with how to build an economic system so that it grows as high as possible, and has not been seriously directed towards building a strong social security system. As a result, while Indonesia continues to be faced with increasingly complex social problems, success in the economic sector is also very vulnerable to shocks. Indonesia needs a development approach that does not only pursue economic growth but is also oriented to aspects of social protection. In essence, social security is a protection strategy to sustain and maintain economic stability. International and national commitments strongly emphasize the importance of social security, especially as a strategy for handling poverty in a systemic, institutionalized, and integrated manner.

Therefore, a development program policy in poverty reduction efforts is needed to answer problems and meet urgent, realistic, and operational needs so that the socioeconomic conditions of the community do not deteriorate further. In other words, it is necessary to improve and develop existing programs to be more targeted and sustainable, thus changing the paradigm of previous development programs which were temporary, relative, and curative towards programs that are part of an integrated social security system that is preventive, proactive, and long term.

In this perspective, there are thoughts about the need for a poverty reduction system through a social security system model. The social security system model demands a paradigm shift, especially regarding the community fund management system in realizing a prosperous and independent society at the local level (district/city), as well as at a lower level of hierarchy by applying the principles of good governance. The development of the social security system is carried out using several main approaches, namely the systems approach, the community empowerment approach, and the institutional approach. These various approaches require different treatments. The community empowerment approach is expected to be more prominent with the approach of 
government programs and projects as support. The existence of this social security system model raises new hopes for poverty reduction towards an independent society.

\section{SOCIAL SECURITY PROGRAM IN INDONESIA}

Social security programs, in fact, have been known in Indonesia for a long time. The Dutch East Indies government, since 1936, has provided health insurance to all Dutch East Indies government employees. This system continued when Indonesia became independent in 1945. It was not until 1968 that the government changed the administration of health insurance for civil servants and pension recipients based on Presidential Decree No. 230/1968, known as the Askes program. Likewise, in administering the old-age pension program, the government then established PT Taspen (for civil servants) and PT Asabri (for members of the TNI and Police). As for private workers, the government established PT Jamsostek. However, whether it is seen from the number of participants, the type of program, and the quality of the benefits, as well as different principles, it can lead to social justice.

Social Security is a government program that aims to provide certainty about the amount of social welfare protection so that every citizen can fulfill his life needs towards the realization of social welfare for all Indonesian people. This protection is needed primarily in the event of loss or reduction of income. Social security is the basic right of every citizen as stated in the 1945 Constitution Article 27 paragraph 2. Universally social security is guaranteed by Articles 22 and 25 of the Universal Declaration of Human Rights by the United Nations (1948), which Indonesia is a signatory to. Awareness of the importance of social protection security continues to grow, as read in the Amendment to the 1945 Constitution, Article 34 paragraph 2, namely "The state develops a Social Security System for all people ...".

The development of a social security system program to support the achievement of people's welfare needs to be seen as an effort to restore the community's ability to achieve its own welfare. Therefore, normative social security must refer to the ability of the community to face a crisis, regardless of the cause. The notion of social security (social security) can be broadly defined as public actions, including those taken by society, to protect the poor and vulnerable from adverse changes in living standards, so that they have an acceptable standard of living (The World Bank Researcher Observer, 1991). Related instruments are job and income security, as well as several formal policy instruments, such as assistance, social insurance, and family benefits. Social security is not to protect the rich but to provide an incentive effect.

In the 1984 ILO study, it was described that there are 3 (three) stages of the evolution of Social Security, namely:

1. Donations from the rich provided for the poor, but the harsh conditions and stigma applied are often unacceptable;

2. The social insurance scheme is developed based on a premium obligation given to participants in the form of pensions and sickness payments; and

3. The concept of prevention to maintain and improve the quality of life.

Social security recognizes several complementary approaches that are planned in the long term to cover the entire society in 
stages according to the development of the economic capacity of the community. The first approach is the social insurance or compulsory social insurance approach, which is financed by contributions/premiums from each employee and employer. The contribution/premium always provides a level of income/wages based on the employer. The second approach is in the form of social assistance (social assistance), both in the form of providing financial assistance and services with financial resources from the state and social assistance and other communities.

Several countries adhering to the welfare state which has provided social security in the form of social assistance have started implementing social insurance. Mainly because security through social assistance requires large funds and does not encourage people to plan welfare for themselves. In addition, the funds collected in social insurance can constitute national savings. Overall, the existence of national social security can support sustainable national development. In terms of its type, social security arrangements consist of health insurance, work accident insurance, employment termination benefits, old-age benefits, pensions, and death benefits.

Meanwhile, in developing countries, the coverage of social security services is still very limited. In Indonesia, for example, universal social security such as pension or death benefits by the state is only given to civil servants, TNI / Polri (Ramesh \& Asher, 2000). In contrast to developed countries, in developing countries, the goal of social security is primarily to prevent or alleviate poverty. Social security in developing countries is mostly developed informally, through kinship and clientelistic relationships (Hall \& Midgley, 2004; Wood, 2004).

Social security (social security) is a type of social policy to address poverty and inequality in society. Every country has different definitions, systems, and approaches to addressing poverty and inequality, and as such, has different social security systems and strategies. Social security is generally implemented in various forms of direct income support (income support) which are closely related to taxation and incomemaintenance policies. However, social security often includes various schemes to increase access to basic social services, such as health care, education, and housing (Huttman, 1981; Gilbert and Specht, 1986; Cheyne, O'Brien, and Belgrave, 1998). Social security in the form of income allowances can be called benefits in cash, while in the form of goods assistance or social services, it is often called benefits in kind (Shannon, 1991; Hill, 1996; MHLW, 1999).

The main reason why social security needs to be given to citizens who do not have a job is to protect citizens from unforeseen risks, also because social security is economically and socially not detrimental to both providers and recipients of services, for example, benefits for people with disabilities caused by an accident so that they cannot work or retire for people who have entered retirement age. Social security requires the existence of a great deal of state interference in social policies or policies for poverty. Social security is not wasted on public expenditure. But it is a form of social investment that is profitable in the long run which is based on two main pillars, namely income redistribution and social solidarity (Spicker, 1995: 58-60). These two principles explain how social security 
mechanisms work. For example, how can the circulation of money rotate among members or social security participants so that a mutual protection mechanism occurs between them which in turn becomes a social investment that contributes to maintaining and improving the quality of life of the nation-state in a sustainable.

Social security also emphasizes the crosssubsidy mechanism from the rich to the poor using vertical and horizontal redistribution of income. Vertical redistribution refers to the transfer of money from the rich to the poor. Here, social security is a form of strong community support for economically weak members of society. Horizontal redistribution is the transfer of money "between groups", that is, from one group to another. For example, from boys to girls, from adults to children, from teenagers to the elderly. Horizontal redistribution can also be "interpersonal", namely from one person's life cycle to another (from one part of an individual's life-cycle to another) which Spicker (1995: 60) calls "income smoothing". In this context, Spicker explained that social security is essentially financial support provided to children who later pay when they become adults; given to a sick person who pays when he is healthy; or given to retirees who paid while they were still working. Social solidarity can take the form of support from community responsibility in providing mutually beneficial assistance or mutual aid and collective action. Mutual support refers to the idea of diversification of risks where every member of the community or organization agrees to share risks and responsibilities in facing uncertainties that may be experienced in the future (Spicker, 1995; MHLW, 1999). Collective action refers to the idea of "fraternity" which sees social welfare efforts as a shared responsibility of all members of society. Social security is a form of social solidarity with members of society, especially vulnerable groups. The state is a representation of society that is responsible for helping this group, which because of their physical (handicapped), cultural (alienated), and structural (unemployed) obstacles, are unable to respond as quickly as the social changes around them, are thrown aside in an unfair development process (Suharto, 2001a; 2001b; 2001c; 2002).

The view of the importance of social security is based on theoretical perspectives and normative decisions about how income should be distributed and what role should be played by the state, family, individuals, and the market in ensuring that a person has a decent income to meet his daily needs. In this context, the social security function can be divided into two spectrums as explained by Cheyne, O'Brien, and Belgrave (1998: 176), namely a) As a system of state financial support that is paid to those persons who are not provided for adequately by the market; and b) As a system of state financial support paid to those persons who are unable to secure adequately. In the first sense, state financial benefits are provided to citizens due to the failure of the market to provide sources of income (employment).

In the second sense, state assistance is given to people who are helpless due to some reason (disability, pregnancy, illness) unable to earn the income as provided by the market. When parsed sharply, the two definitions above are strongly influenced by the two paradigms of neo-liberal and social democrats that view poverty from an individual and a structural perspective. This view is then the 
basis for the formulation of social security and its approaches (see Table 1).

Table 1. Neo-Liberal and Social Democratic Views of Poverty

\begin{tabular}{|c|c|c|}
\hline & Neo-Liberal & $\begin{array}{c}\text { Social } \\
\text { Democratic }\end{array}$ \\
\hline $\begin{array}{l}\text { Theoretical } \\
\text { Basis }\end{array}$ & Individual & Structural \\
\hline $\begin{array}{l}\text { Causes of } \\
\text { Poverty }\end{array}$ & $\begin{array}{l}\text { Individual } \\
\text { weaknesses and } \\
\text { choices; weak } \\
\text { income } \\
\text { regulation; weak } \\
\text { personality (lazy, } \\
\text { resigned, stupid) }\end{array}$ & $\begin{array}{l}\text { Inequality of } \\
\text { economic and } \\
\text { political } \\
\text { structures; } \\
\text { social injustice }\end{array}$ \\
\hline $\begin{array}{l}\text { Poverty } \\
\text { Reduction } \\
\text { Strategy }\end{array}$ & $\begin{array}{l}\text { Selective } \\
\text { distribution of } \\
\text { income to the } \\
\text { poor; provide } \\
\text { financial } \\
\text { management } \\
\text { skills training }\end{array}$ & $\begin{array}{l}\text { Universal } \\
\text { distribution of } \\
\text { basic income; } \\
\text { fundamental } \\
\text { changes in the } \\
\text { patterns of } \\
\text { distribution of } \\
\text { income through } \\
\text { state } \\
\text { intervention }\end{array}$ \\
\hline $\begin{array}{l}\text { Social } \\
\text { Security } \\
\text { System }\end{array}$ & Social Insurance & $\begin{array}{l}\text { Social } \\
\text { Assistance } \\
\text { (Corporate } \\
\text { Social } \\
\text { Responsibility) }\end{array}$ \\
\hline Principle & Mutual Aid & $\begin{array}{l}\text { Vertical and } \\
\text { horizontal } \\
\text { redistribution of } \\
\text { income; } \\
\text { collective action }\end{array}$ \\
\hline
\end{tabular}

Source: Developed from Cheyne, O'Brien dan Belgrave (1998: 176)

The neoliberal theory has its roots in classical political work by Thomas Hobbes, John Lock, and John Stuart Mill which essentially argues that an essential component of society is individual freedom. In the economic field, the monumental work of Adam Smith, the Wealth of Nation (1776), and Frederick Hayek, The Road to Serfdom (1944), is seen as a reference for neoliberal people who put forward the principle of laissez-faire, which Cheyne, O'Brien, and Belgrave (1998: 72) is referred to as an idea that proposes "the almost complete absence of state's intervention in the economy." Broadly speaking, neo-liberal proponents argue that social security should be provided by self-help groups, religious institutions, or by families. The role of the state is only as a "residual agent" or "night watchman" who can only interfere when the above institutions are no longer able to carry out their duties (Shannon, 1991; Spicker, 1995; Cheyne, O'Brien and Belgrave, 1998). Although theoretically, the neo-liberals reject the responsibility of the state in social welfare efforts, in practice they only propose the readjustment of social welfare programs, rather than eliminating them. Based on the public-choice theory, agency theory, and transaction-cost theory, they basically want to replace the influence of politicians and interest groups in policymaking, with decisions based on consumer interests in line with the principles of free-market economics. The application of structural adjustment programs in several countries is a concrete example of the neoliberal influence in the social welfare sector.

In the market mechanism, the social security approach which is naturally considered capable of overcoming poverty and social inequality has received criticism from social democrats. Based on the analysis of Karl Marx and Frederick Engels, supporters of social democrats state that "a free market does not lead to greater social wealth, but greater poverty and exploitation... a society is just when people's needs are met, and when 
inequality and exploitation in economic and social relations are eliminated "(Cheyne, O'Brien and Belgrave, 1998: 91 and 97). Social democratic theory pivots on the principles of a mixed economy (mixed economy) and Keynesian economic management. This theory emerged as an answer to the economic depression that occurred in the 1920s and early 1930s. Welfare state systems that emphasize the importance of state management and funding in the delivery of basic social services, such as education, health, housing, and social security, are heavily influenced by this Keynesian style of "demand-management economics". Although they do not fully agree with the free market system, social democrats do not view the capitalist economic system as evil. Even capitalists are still seen as the most effective form of economic organization. It's just that capitalism needs to be equipped with a welfare state system to make it more humane. "The welfare state acts as the human face of capitalism," according to Cheyne, O'Brien, and Belgrave, (1998: 79).

The social democrat approach raises social security programs in the welfare state approach with an institutional model. The institutional welfare model is based on society and the state which is based on consensus values, but confirmation is achieved through a process of social integration, not just emphasizing aspects of individual choice. About the role of the state in providing welfare services in the form of social security programs to the community, this model sees the government as having to collaborate with the private sector and for-profit organizations in improving service quality. This is done because social welfare efforts are considered to be necessary and functional for the realization of social integration. The institutional model is proactive because this model is based on the assumption of humanitarianism, where welfare is the right of every citizen. One of the main points of this humanitarianism approach is an attempt to reduce the negative stigma of service recipients as to what happens to the residual model. Therefore, the assistance given to community members who are in need (in crisis conditions) is more proactive in nature and not reactive in nature.

In the institutional model, the role of the government is more active in ensuring the welfare of its citizens than before. The form of social services provided is not only given to certain groups such as the residual model but is considered to be every citizen's right. Seeing that this institutional social welfare system is developed is not a reaction to a crisis in the market and family system. But this social welfare system was developed because of the awareness that nowadays people live in a complex system so that difficulties can arise at any time. Therefore, it is necessary to develop institutions that deal with emerging social problems. For example, because it is realized that in an increasingly complex and tiring labor system, work accidents are more likely to occur. So, the government developed a social security system as well as compensation for people who had problems. This system is prepared not as a reaction to social problems such as work accidents, but as a proactive action by the government to anticipate work accidents. In this connection, the institutional model sees social welfare as a regular, permanent service system that must exist in every structure of society.

Social democrats argue that equality is an important precondition for attaining 
independence and freedom. The attainment of freedom is only possible if everyone has or can reach resources, such as education, good health, and sufficient income. Freedom is more than just being free from outside influences; but also free in determining choices (choices). In other words, freedom means having the ability to do or not do something. For example, the ability to meet basic needs, the ability to avoid premature death, the ability to avoid malnutrition, the ability to read, write, and communicate. The state, therefore, has a role to play in ensuring that everyone can participate in social transactions which enable them to make choices and meet their needs. Social security, according to the viewpoint of social democrats, can increase freedom because it can provide basic income with which people will have the ability to meet needs and determine their choices. Conversely, the absence of basic social security can lead to dependency because it can make people unable to meet their needs and make choices.

Thus, what is meant by social security is the ability of the community independently to continue to develop and to be aware of, prevent and overcome crises, which originate from internal and external factors, so that just social welfare can be realized. In this sense, several things need attention, namely:

1. Definition and scope of society. Often, the discourse of talking about the welfare of society places the community as a different party from the government, different from the big private entrepreneurs. When viewed from a humanitarian perspective as above, what is meant by society is humans who are assembled based on a reason, such as organizational, geographical, institutional, and other things. The difference in position or status is only a form of differentiation of roles and functions in one unified society. Therefore, the definition of community (community) can also be defined as the people (people), more than a citizen, which includes elements of the population, government, businessmen, NGOs, and so on. Then, the government system is called governance.

2. Definition of independent. Independency or independence is often translated as selfreliance, which means using one's own resources, working alone, and in a selfcreated (closed) environment. In the past, this may have had strong supporters. However, in an all global and open environment, this can no longer be sustained. Therefore, the definition of "independently" is defined as the ability to make their own decisions in utilizing all possible resources, including outside assistance to achieve goals. This is by the current trend of the world, namely the change from global dependence to local interdependence or even smaller individual interdependence that is identical to the relationship.

3. Understanding to be aware of, prevent, and overcome. This has dynamic and anticipatory dimensions. Only with the ability to be aware, bad events or crises that will occur can be prevented or minimized the risk. Even if this bad incident happened due to a disaster or calamity factor, the community independently could still minimize the risk. Thus, they also have the meaning of a continuous and continuous process.

4. The definition of "crisis" itself. In this limitation, what is meant by crisis is 
anything that disturbs and damages many aspects of society in a very substantial scope and time, so that it is dangerous and keeps society away from the goal of welfare.

5. Definition of just welfare. Namely the welfare obtained without the exploitation of one of the members, or one part of society, or society itself as a whole, and the welfare rewards received are by the contributions given. In this context, human relations are more substantive-functional.

Based on the definition of social security above, what is meant by a social security system is a series of related components that are synergistic to create social security in an area. This limitation regarding the social security system then limits the scope of social security itself, namely:

1. Family Empowerment. The social security system in a community area is determined by the process of empowering the family as the smallest social and kinship unit in the community. If the family can realize the ability to meet needs, social security will be easier to achieve.

2. Community Territory. Social security encompasses regional empowerment, in the sense that a social security system is built starting from the area of community resilience that supports planning and decision making for the development of a social security system. The most appropriate environments are at the village, settlement, or - in certain conditions - hamlets or equivalent customary kinship. Thus, social security at the national level is built on the social security of each region by taking into account the posts of each region.
3. Creative Social Energy Empowerment. Social energy is the ability of the community to jointly utilize the various available resources. This energy is the main force that enables the development of a system of people's sovereignty (Sumardjo, 1994; Sayogyo, 1994; Uphoff, 1992).

The social security system is built and implemented by empowering the creative social energy that exists in society. In line with the scope of community area resilience and the understanding of independence, the main basis for the Social Security System rests on the social energy of the community itself. Although support is needed, this support is an opening and accessibility of the community to resources and how to use them. Another support is the process of raising awareness and providing knowledge about the actual ability of the community to be able to cope on their own.

Referring to Uphoff's limits (Sayogyo, 1994), social energy comes from 3 (three) interrelated elements, namely: i) Ideas are the result of progressive thoughts that appear and are accepted together. Ideas can come from within or from outside the social unit; from within or from outside the community group. Usually, this kind of idea is accepted by the community because it is considered beneficial for the community to meet the people's needs. Such ideas can change according to the development of community needs so that they always contain tangible benefits and can become a reference for people's thinking and behavior patterns in social life; ii) Ideals (ideal) are hopes or common interests, namely a form of mutual welfare as a result of the realization of ideas (ideas). In this case, the 
basic norm applies: "do for others as others do for you." This ideal can become a kind of idealism of the society concerned so that in every member of the community there is a drive or motivation to make it happen, and iii) Brotherhood (friendship) is a form of solidarity in a social unit as the main force in the process of achieving a confirmed ideal. Solidarity emerges institutionally in local institutions because it is based on equality and agreement on expectations or interests (ideals) that are realized and shared, and want to be realized in certain social systems. The existence of these three elements of social energy is the basis for mutual help cooperation and the development of social care in the context of social security.

Local Institutional Empowerment. Consistent with the above thinking, a Social Security System is built and implemented by utilizing existing local institutions. The formation of a new institution is not a development priority. New institutions will be built if the community itself forms them and the old institutions are no longer able to carry out the functions required in developing the Social Security System by the needs and demands of the times. One of the important aspects that need to be done by and with the empowerment of local institutions is determining or evaluating poverty (poverty assessments). The implementation of poverty assessments takes longer and also requires more resources. However, the results obtained can largely determine the success of the entire social security system itself. The involvement of local institutions in terms of organizations, norms, regulations, and local individuals will provide benefits: (a) Consistency, increased understanding of the dynamics of cultural, social, economic, and political aspects related to social security aspects; (b) Reality, ensuring that the development strategy that will be carried out truly reflects the real conditions in society, is realistic, and can be carried out by the community itself; (c) Sustainability, encouraging the growth of a sense of belonging so that responsibility is born to maintain and sustain the system; and (d) Stimulation, building social capacity to develop programs that may initially have been built with outside assistance.

\section{SOCIAL SECURITY ASPECTS}

The aspects of social security to be developed need to cover: food security, health, clothing, work and business, housing, and education. This sequence is thought to be the order of people's sensitivity to crises. This means that if a crisis hits, education will be sacrificed first, and if it has reached a food crisis, the condition that occurs is already a very serious disaster. But from the government's point of view, services must be prioritized on the aspects of education, health, food, and work and business.

1. Food. Food security can be observed from 3 (three) dimensions, namely: a) Dimensions of national targets; b) The dimension of time or season; and c) The socio-economic dimension of food. The achievement of food security can be seen from the availability of food, food production, food consumption, nutritional consumption, and nutritional status. Efforts to achieve food security down to the household level can be pursued through increasing the effectiveness and efficiency of food distribution, increasing people's purchasing power, increasing the ability to supply food, increasing the 
formation of food reserves, and increasing knowledge of food and nutrition (Suharjo, 1996). Based on the agreement of the World Food Summit (1996), food security is the ability to meet the food needs of household members in quantity, quality, and variety according to local culture from time to time to live a healthy and productive life. The definition of household food security used in Indonesia has not yet socialized this international agreement, because the formal definition of food security used is limited to the availability of sufficient, quality, and safe food in the household, as mandated in Law No. 7/1996. If food is the basic need of a household or community, then food security is the most important aspect of the social security system.

2. Health. The health of each family member is an absolute prerequisite for being able to work productively, generating income that will be used to fulfill other life necessities. Although family food security will determine the health of family members, the health of family members can also be determined by non-food factors, such as pathogenic infections, health services, and environmental changes. Therefore, health security is one aspect of social security. Minimal effort to survive is free from a serious illness. This is often not fulfilled by family members. Based on these considerations, the health aspect of social security indicates a family's ability to access health services for every family member who has serious health problems.

3. Clothing and Housing. Clothing and housing is necessity to minimize the risk of environmental changes that will have an impact on health problems. Besides that, clothing and housing are also vehicles to fulfill the socio-psychological needs of the family and its members. Based on this, the selection of clothes in quantity and quality can be used as an indicator of clothing security. Likewise with housing. The quality and floor area of a house that is owned can be used as an indicator of meeting the needs for housing or housing in the context of social security.

4. Effort and Work. Work is the main source of community income. However, work is often the basis of a person's or a family's existence. As the conditions of the crisis show, losing a job is the first blow to trigger another form of welfare. Inclusion of work and business security as an aspect of social security and not income is an effort to provide better sustainability guarantees, as well as to correct possible problems of purchasing power, closed accessibility, lack of need, and to reduce manipulative implementation.

The aspect of job security and business can be interpreted as the ability of the community to continue to maintain the availability of job opportunities and provide business opportunities for community members in various conditions and through certain social mechanisms. This has resulted in many policy consequences, from the macro (national) to the household level. Some of them are: a) Promotion of economic activities based on local resources and local markets; b) Develop various economic modifiers (exchange rates, interest rates, government budgets, taxes, etc.), which are friendly to the development of economic activities of the majority of the people; c) Adapt savings and reserves starting at the national, regional, 
village and household levels; and d) Cultivate good business habits through the introduction of the resources owned and the prospects for the type of business.

\section{SOCIAL SECURITY MECHANISM IN INDONESIA}

The social security system broadly follows two methods, namely social insurance and social assistance (MHLW, 1999). Social insurance is social security provided to insurance participants based on the premiums they pay. Health insurance and pension systems are two forms of social insurance that are commonly applied in many countries. Social assistance is social security which is generally provided to weak groups in society who, although they do not pay premiums, can receive income support or social services. Social welfare programs for children, persons with disabilities, the elderly are some examples of social assistance.

Both social securities in the form of social insurance and social assistance are generally managed by following a basic strategy, namely: 1) Universal and selectivity, namely universal social security provided comprehensively to all citizens. Meanwhile, social security selectivity is only given to certain groups through targeting (selectivity), for example, the poor; 2) In-cash and in-kind refer to the types of benefits or allowances in social security provided in the form of money (income transfer), while in-kind is the type of social security benefits in the form of goods or social services (benefits in kind); and 3) Public and private that social security can be administered by the state (public) or by private institutions which are generally in the form of Limited Liability Companies.
Social security can be provided through a social insurance system that is funded by insurance premiums or through social assistance whose funds are obtained from tax revenues. Social insurance is defined based on insurance expertise. The provision of insurance benefits is calculated based on the insurance premium. In principle, the central government together with other public institutions is the provider of social insurance. Social insurance membership is obligatory. The medical insurance system and pension insurance are two very broad types of social insurance. Social assistance is not defined by insurance expertise. Social assistance benefits are provided based on funds raised from tax revenues. The central and local governments provide money or social services to the population as a form of state concern or obligation to fulfill the basic rights of their citizens. The public assistance system is a typical example of social assistance. As well as social welfare programs for children, people with disabilities (ODK), and the elderly; Social assistance also includes allowances for families (generally single or underprivileged families) who have dependent children and welfare pensions. In the United States, one of the well-known forms of social assistance is AFDC (Aid for Families with Dependent Children) which has now changed to TANF (Temporary Assistance for Needy Families) (Chambers, 2000).

In designing social security mechanisms, determining the type of system, whether to be in the form of social insurance or social assistance, depends largely on the purpose and content of the system, as well as on historical changes in the environment of the country concerned. Around the world, medical security and old-age income security 
systems are generally provided in the form of social insurance, such as medical insurance and pension insurance. The mechanism for implementing the National Social Security System includes membership, fees, benefits/benefits, and investment arrangements. The expansion of the membership coverage is carried out gradually in accordance with the economic conditions of the country and the community, as well as the ease of routine recruitment and collection. The amount of contribution/premium is calculated based on actuarial analysis which is adjusted to the benefits program to be provided, the demographic structure and trend, as well as the risks, faced, determined in a certain percentage of wages taking into account the ability/income of the population. Contributions/premiums are borne jointly by employers and workers. Compensation and claim services are adjusted according to the amount of contribution and the type of program being followed. The benefits provided must be significant enough to encourage greater participation over time. The dues/premiums/participant contributions that are collected need to be managed and supervised by a Board of Trustees and only used for the benefit of the participants in accordance with the prevailing laws and regulations. Some of the funds raised need to be invested and developed as safely as possible. Due to the non-for-profit principle, the investment returns will be returned and used maximally for the benefit of the participants. To be able to guarantee the effectiveness and efficiency of its operation, it is necessary to have the support of a Management Information System as well as reliable Human Resources capabilities. In its management, it is necessary to implement good corporate governance (transparency, objectivity, accountability, and responsibility). The form of social security can be broadly divided into social insurance, social assistance, provident funds, employer mandates, and social allowances (Hall \& Midgley, 2004).

\section{COMPONENTS OF SOCIAL SECURITY IN INDONESIA}

The Social Security System to be built needs to be composed of components in a complete work system, namely:

1. The local resilience system describes the mechanisms and community organizations to be able to overcome crisis problems at the local level by utilizing or exploiting the resources available in the regions. This can be realized through a) Development of local resources; and b) Development of local organizations.

2. Government funds or programs to deal with socio-economic problems and crises. Various aid programs have been implemented by the government to help families that are classified as poor so that they can improve their quality of life towards a better condition. In the welfare family development movement, program assistance is provided by the problems faced by each family. However, in broad outline, this government assistance program is aimed at improving and increasing the control of the family economy.

3. Community socioeconomic welfare mechanism (Social Insurance). The social insurance system is basically a manifestation of the government's commitment that every citizen has the right to receive reasonable protection to 
fulfill his basic needs. Social insurance programs deal with basic risk management for a person. Based on Law no. 2/1992 regarding insurance business, several characteristics distinguish it from social insurance, namely: a) It is mandatory, social insurance applies the open-ended group concept because of the principle of compulsory inclusion for all workers who are informal groups of workers, as well as those in groups non-formal; b) Basic benefits, must be able to provide benefits deemed sufficient to meet the basic needs of the community without having to significantly reduce the market share of the commercial insurance sector; c) Cross subsidies, functioning as a means to carry out redistribution of income, which is one of the development objectives. Its implementation is needed in a planned and cooperative manner so that those who can help the less fortunate and high-risk groups are assisted by low-risk groups; and d) Run by a state-owned company, a social insurance implementing agency must be created by the government. Fund placement programs are only carried out on government instruments that are fully guaranteed and it must be ensured that the government uses these funds to finance national development programs.
4. Foreign assistance. With limited government funds, people are now able to increase access to foreign parties. In a social security system, foreign assistance can still be used as alternative funding, but not in large amounts. This is intended to avoid dependence and indulgence that cause difficulties to be independent. Therefore, foreign assistance is one component of the social security system. Creativity to create mutualistic cooperation with foreign parties must be stimulated as widely as possible.

5. National Economic Development. National economic development leads to economic growth which is important for providing employment opportunities and growing income, demand, and supply. The social security system is greatly influenced by the success of national development, because the power to develop a social security system in each subsystem component is largely determined by the empowerment of the community in general, especially in meeting needs, increasing income, increasing savings, and so on; which is an element of progress at the economic level of society.

\section{Gambar 1: Kaitan antar komponen}

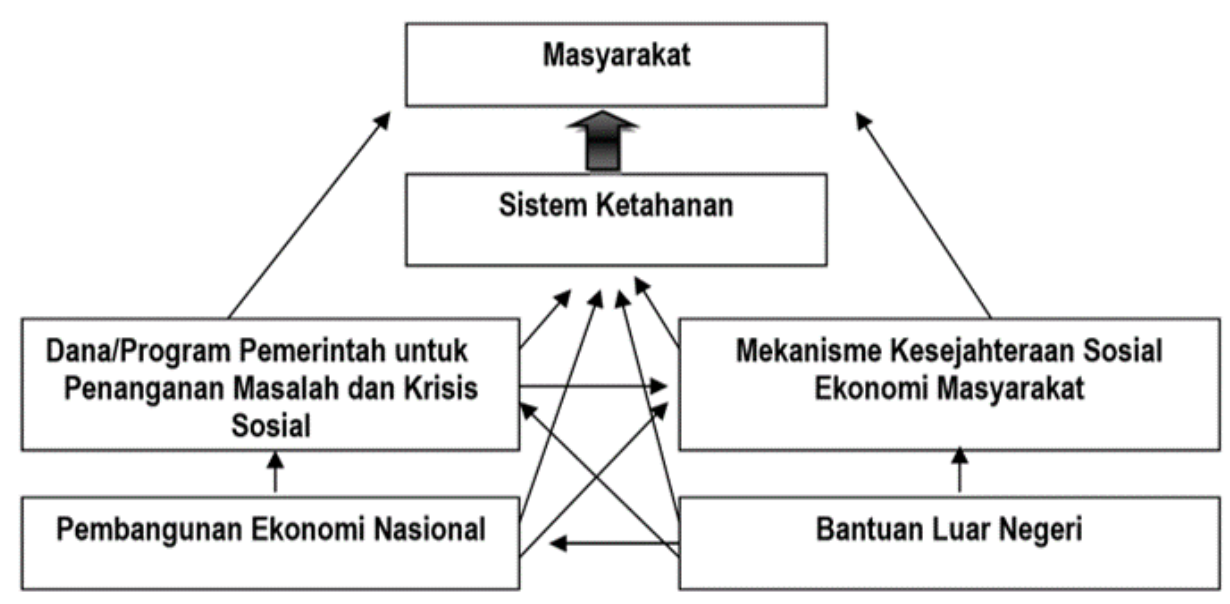


Basically, the direction of the development of the social security system is the need for a paradigm shift, especially regarding the problem of the public fund management system in realizing a prosperous society, towards a just and prosperous society, with the characteristics of developing independence, both at the local (district) level and the lower hierarchical level, by applying the principles of good governance.

In this perspective, the development of a social security system to support the achievement of social welfare is not absurd. The development of this system needs to be seen as an effort to restore people's ability to achieve their own welfare. In other words, in realizing humanistic and sustainable development in which every element of society feels the results, the development of a community empowerment approach will increase the effectiveness and efficiency of using the increasingly scarce community development resources. This approach will increase the relevance of the development program (government) to local communities and increase its sustainability, by encouraging a sense of community ownership and responsibility. Also, this approach has a contribution to improve the performance of government staff and customer satisfaction with government services.

In Indonesia, the social security component is administered by the social security program administering body in Law no. 40/2005 is the existing Social Security administering bodies (PT Jamsostek, PT Askes, PT Taspen, and PT Asabri) without precluding the formation of other administering bodies, which are established by law (article 5, paragraph 1). In-Law no. 40/2004, the types of components of the Social
Security program to be implemented include (1) Health Insurance; (2) Work Accident Benefits; (3) Old Age Security; (4) Pension Guarantee; (5) Death Insurance; and (6) Health Insurance.

\section{CONCLUSION}

As a conclusion, lessons learned for Indonesia to overcome the obstacles faced in developing a social security system as an alternative to improve people's welfare, namely: Improving the implementation mechanism of social assistance programs that are not centralized, which accommodate the diversity of characteristics and local demands. Meanwhile, every region in Indonesia has a different standard of living. Strong integration and relationship between management of fields of economic development (industry, trade, manpower); social development (health, education, housing); with the field of social welfare. So that the effectiveness of the achievement of programs in the field of people's welfare can be achieved, which is marked by an increase in the level of people's welfare. Insurance and social security guarantees can improve the quality of life of the poor and provide a more meaningful spirit of life. The current insurance and social security system are still discriminatory, limited only to those who have money. For this reason, the government is obliged to provide adequate insurance coverage to the poor. The regional development agenda prioritizes poverty eradication as the main priority scale, encourages the determination of all parties to acknowledge the failure of poverty reduction so far, raises collective awareness to understand poverty as a common enemy, and increases the participation of all parties in eradicating poverty. Those who are 
responsible for preparing the expenditure budget must realize the importance of improving people's welfare so that these efforts are placed and receive top priority in every program in each agency. Provide the widest possible space for the emergence of various community initiatives and creativity at various levels (community empowerment). In this case, the government plays a more role only as an initiator, then acts as a facilitator in the process, so that in the end, the framework and approach to poverty reduction are mutually agreed upon. Opening up business opportunities and opportunities for the poor to participate in the process of economic development. The government should create a climate so that economic growth can be enjoyed by all levels of society, especially the poor. Therefore, pro-poor policies and programs need to focus on the real economic sector (for example; agriculture, fisheries, manufacturing, small and medium enterprises), especially in the informal sector which forms the backbone of the poor. There is a need for Policies and Programs to Protect the Poor. The poor are very vulnerable to internal shocks (for example, the head of the family died, fell ill, was laid off) as well as external shocks (for example, loss of a job, natural disasters, social conflicts) because they do not have the resilience or security in facing these shocks. Required Policies and programs include efforts to; (a) reduce sources of shock risk; (b) increasing the ability of the poor to cope with shocks and; (c) creating an effective social protection system. It is necessary to redefine the meaning of social solidarity among community members through an increased understanding of the need to share the coverage and benefits of social security for different groups and generations. Besides, the social security system needs to be strengthened as a social capital infrastructure for people to lead a stable life. In line with the strengthening of the spirit of civil society, the proliferation of social organizations is a vehicle for thickening social capital. Decentralization and regional autonomy need to be followed by strengthening local integrity and potential in managing sources of funding for social security (for example, zakat mal) through community development and social participation programs.

\section{REFERENCES}

A Victorian Government Initiative. 2006. A Fairer Victoria: Progress and Next Steps. Australia, State of Victoria.

Beddie, Francesca. 2001. Putting Life Into Years. Australia: The Commonwealth Department of Health and Aged Care.

Best of OTOP. 2006. The Unlimited Wisdom. Bangkok.

Colin Morison. 2006. Local Government in Victoria. Victoria: Department for Victorian Communities.

Crescent, Tim. 2003. Menuju Masyarakat Mandiri: Pengembangan Model Sistem Keterjaminan Sosial (Terjemahan). Jakarta: PT. Gramedia Pustaka Utama.

Jamasy, Owin. 2004. Keadilan, Pemberdayaan dan Penanggulangan Kemiskinan. Bandung: PT. Mizan Publika.

Pusat Kajian Administrasi Internasional. 2006. Kajian Analisis Kebijakan Sistem Keterjaminan Sosial Menuju Masyarakat Mandiri. Jakarta: LAN.

The Department for Victorian Communities and Community Development Finance. 2005. Victoria.

Undang-Undang Dasar 1945 beserta Amandemen

Yayasan TIFA. 2005. Semua Bisa Seperti Jembrana. Jakarta. 